Biografistyka Pedagogiczna

Rok 6 (2021) nr 2

ISSN 2543-6112; e-ISSN 2543-7399

DOI: $10.36578 /$ BP.2021.06.49

\title{
Alicja Żywczok*
}

\section{Odwaga, dzielność, męstwo oraz ich przeciwieństwa. O odkrywaniu dziedzictwa mistrza Wincentego Kadłubka}

\author{
Courage, Bravery, Prowess and Their Antonyms.
} A Study in the Heritage of Master Wincenty Kadłubek

\begin{abstract}
In view of the rare reception of pedagogical thought of Wincenty Kadłubek, a medieval thinker and chronicler, the author of this article decided to examine this part of Wincenty Kadłubek's literary output, which can be related to axiology (the theory of values) and arethology (the theory of virtues). Apart from ethical provenance, the categories of "courage" and "bravery" have strong scientific roots in pedagogics and its numerous sub-disciplines. The significant meaning of these categories manifests itself in the spheres of theoretical and practical (applied) pedagogics. This is why beside containing a sketch of the specific features of the epoch, in which this outstanding Polish intellectual lived and created, and alongside a concise study of the chronicle and the biographical facts, this article also addresses several research problems: how does Wincenty Kadłubek perceive courage and bravery? How does he understand the "origin"/genesis of the human courage and bravery? To what other values and virtues are they, in his opinion, most closely related? What significance does the chronicler assign to personification of bravery and courage? What factors, in his opinion, hinder these values, and what are their antonyms? How does he propose to overcome all that thwarts bravery and courage, and what advice does he have for educational shaping of bravery? The author undertakes a hermeneutic interpretation of the lesser known output of Wincenty Kadłubek in the belief that it belongs to the Polish cultural capital and a treasury of tradition, and that it continues to offer much not only to Polish researchers but also to individual recipients.
\end{abstract}

Keywords: value, virtue, axiology, arethology, courage, bravery.

* Alicja Żywczok (ORCID: 00oo-0003-3994-9558) - dr hab. prof. Uniwersytetu Śląskiego, pedagog i filozof, pracuje w Instytucie Pedagogiki na Wydziale Nauk Społecznych Uniwersytetu Śląskiego w Katowicach; kontakt: alicja.zywczok@us.edu.pl. 


\section{Wprowadzenie}

W

incenty Kadłubek, autor dzieła Chronicon Polonorum ${ }^{1}$ (Kronika polska), należy do postaci spopularyzowanych w rodzimej edukacji szkolnej. Warto jednak przyjrzeć się mniej znanemu fragmentowi osiągnięć dziejopisarskich kronikarza, który daje się zakwalifikować zarówno do dorobku aksjologii ujmowanej jako teoria wartości, filozofia wartości albo odrębna dziedzina interdyscyplinarna, jak i do dorobku aretologii. Aretologia, od gr. areté - „to, co najlepsze”, „dzielność”, „cnota”; logos - „myśl”, „rozważanie”, „wyjaśnienie”, to jeden z podstawowych działów etyki i teologii moralnej, którego przedmiotem jest pojmowanie, koncepcje i klasyfikacje cnoty, relacje między poszczególnymi jej składnikami, sposoby osiągnięcia i zachowania cnoty. Aretologia bywa określana jako teoria cnót ${ }^{2}$.

Kolejne analizowane w artykule kategorie: „odwaga”, „dzielność” i „męstwo” mają, oprócz oczywistych związków z etyką, wyraźne usytuowanie naukowe w dyscyplinie pedagogika i jej subdyscyplinach, zwłaszcza w teorii wychowania, pedagogice ogólnej, historii wychowania (i historii myśli pedagogicznej), a także w pedagogice kultury. Nie sposób nie dostrzec również powiązań podjętej problematyki z interdyscyplinarnymi obszarami poznania określanymi jako aksjologia pedagogiczna oraz biografistyka pedagogiczna. Należy zaakcentować, że istotne znaczenie tych kategorii ujawnia się w obszarze pedagogiki teoretycznej oraz praktycznej, w których odwagę pojmuje się zwykle jako gotowość jednostki do działania mimo spostrzeganego lub doświadczanego przez nią zagrożenia czy trudności w celu osiągnięcia pozytywnych rezultatów dla niej samej lub dla innych ludzi ${ }^{3}$. Warto dodać, że odwaga należy do wartości zarówno indywidualnych, jak i społecznych. Kwalifikuje się ją także do klasy

1 Magistri Vincentii dicti Kadłubek Chronicon Polonorum, wydał, wstępem i przypisami opatrzył M. Plezia, seria: Monumenta Poloniae Historica. Nova series, t. 11, Kraków 1994.

2 Hasło Aretologia, w: Słownik przewodnik filozoficzny. Osoby - problemy - terminy, red. A. Maryniarczyk i in., Lublin 2012, s. 362.

3 A. Wenc, Odwaga, w: Encyklopedia aksjologii pedagogicznej, red. K. Chałas, A. Maj, Radom 2016, s. 678. 
wartości moralnych. Z kolei analizowane w artykule dzielność oraz męstwo ${ }^{4}$ należą do klas cnót kardynalnych oraz etycznych.

W pedagogice stosowanej istotę wychowania można sprowadzić do dodawania młodemu człowiekowi odwagi do spełnienia właściwych pod względem etycznym czynów i działań. Wyraźna zachęta rodziców, by ich dziecko wykonało pierwszy krok (dosłownie i symbolicznie), jest niczym innym jak próbą dodania mu odwagi. Potoczna wypowiedź: „zrób pierwszy krok” jest sugestią, by ktoś zdobył się na akt odwagi w tzw. trudnej dla niego sytuacji. Uczynienie „pierwszego kroku” w jakiejś ważkiej kwestii, np. w geście przebaczenia, staje się świadectwem nie tylko ukształtowania pożądanej dzielności jako cechy, lecz także dojrzałości emocjonalnej, moralnej i społecznej człowieka ${ }^{5}$. Odpowiednikiem popularnego dziś powiedzenia: „Do odważnych świat należy”, które podkreśla znaczenie odwagi, jest np. fragment dzieła Kadłubka: „Dzielność bowiem znajduje na bezdrożach nie tylko ścieżkę, nie tylko drogę - ba, królewski gościniec ściele się wszędzie przed odwagą"6. Te trafne słowa mogą - jak sądzę zachęcić współczesnych badaczy do studiowania oraz wspomagania się niezwykłym dziedzictwem Wincentego Kadłubka.

Choć utarło się przekonanie, że Kronika polska jest utworem niezrozumiałym, ułożonym przez autora raczej w celu zakamuflowania niż jasnego przekazu treści odbiorcy, zawartość dzieła z powodzeniem poddaje się deszyfryzacji, dlatego też wielu badaczy, np. Marian Plezia ${ }^{7}$ czy Teresa Michałowska, pogląd ten kwalifikuje jako polemiczny ${ }^{8}$. Kronikę można przecież postrzegać także jako doskonałe studium kultury chrześcijańskiej, które wniosło niezaprzeczalny wkład w obecną jakość socjologiczną zwaną Europą ${ }^{9}$. Dwujęzyczne piśmiennictwo polskiego śre-

4 Tomasz z Akwinu, Suma teologiczna, t. 21: Męstwo, przeł. S. Bełch, P. Bełch, Londyn 1962.

5 A. Żywczok, Reaktywowanie idei odwagi i etycznej dzielności w wychowaniu dzieci i młodzieży, „Chowanna”, 1 (2008) s. 38; tejże, Formy odwagi ludzkiej i sposoby jej identyfikacji w procesie wychowania, „Kwartalnik Pedagogiczny”, 1 (2008) s. 55-68.

6 Mistrz Wincenty Kadłubek, Kronika polska, przeł. B. Kürbis, Diepholz 2009, s. 143. Wydanie oparte na publikacji Zakładu Narodowego im. Ossolińskich - Wydawnictwo z $1996 \mathrm{r}$.

7 M. Plezia, Retoryka Mistrza Wincentego, „Studia Źródłoznawcze”, 20 (1976) s. 88-94.

8 T. Michałowska, Literatura polskiego średniowiecza wobec poetyki europejskiej („Ornatus difficilis”), Warszawa 2008, s. 130.

9 Ch. Dawson, Szkice o kulturze średniowiecznej, przeł. J. Sulowski, Warszawa 1966, s. 7. 
dniowiecza było badane w ciągu XIX i XX wieku zwłaszcza przez historyków, językoznawców, wersologów, muzykologów. Dociekania te przyniosły odkrycie wielu tekstów i zaowocowały znakomitymi niekiedy analizami oraz edycjami krytycznymi bądź popularnonaukowymi licznych zabytków. Rezultaty owych prac tworzą dziś trudną do przecenienia podstawę wiedzy o początkach narodowej literatury. Dotyczy to przede wszystkim dzieł pisarzy (np. Galla Anonima, Mistrza Wincentego, Wincentego z Kielczy, Władysława z Gielniowa), rzadziej gatunków (np. sekwencji, dramatu liturgicznego, hymnu $)^{10}$.

W artykule zostały zawarte propozycje rozwiązania zogniskowane wokół kolejnych postawionych tu problemów badawczych. Jak Wincenty Kadłubek postrzega odwagę, dzielność i męstwo? Jak ujmuje genezę ludzkiej odwagi, dzielności i męstwa? Z jakimi innymi wartościami i cnotami są one w jego opinii najsilniej związane? Jakie znaczenie przypisuje kronikarz przejawianiu dzielności i męstwa? Co stanowi - w jego przekonaniu - ich przeciwieństwa? Jakie przekazuje wskazówki odnośnie do przezwyciężania tych przeciwieństw, a więc także do wychowawczego kształtowania dzielności i męstwa?

W badaniu problematyki odwagi (ujmowanej jako wartość ${ }^{11}$ ), a także dzielności oraz męstwa (ujmowanych jako cnót ${ }^{12}$ ), rozpoznanych w dorobku naukowym

10 T. Michałowska, Szkice mediewistyczne, seria: Studia Staropolskie. Series Nova, t. 40 (96), Warszawa 2014, s. 193, 194.

11 Wartość to wszystko, co cenne dla jednostki bądź społeczności, godne pożądania i wyboru, co stanowi cel ludzkich dążeń i łączy się z pozytywnymi przeżyciami. Nierzadko uchodzi za kryterium oceny ludzkiego zachowania, relacji interpersonalnych, zasad postępowania, procesów, rzeczy itp. Podstawowa kategoria aksjologii; Stownik pojęć filozoficznych, red. W. Krajewski, Warszawa 1994, s. 207. Wartość (łac. valor „atut”) to coś, co budzi uznanie człowieka. W metafizyce realistycznej - właściwość bytu; w filozofii Immanuela Kanta - korelat powinności; Stownik przewodnik filozoficzny, s. 502. Wartości to transcendentalia lub istotności o specyficznej budowie materialno-niematerialnej i określonym sposobie istnienia; W. Stróżewski, Istnienie i wartość, Kraków 1981, s. 102.

12 Główne pojęcie „aretologia”: cnota (od gr. arete; łac. virtus) - cecha osobowa człowieka; czynnik wewnętrzny usprawniający do realizacji dobra moralnego; trwała dyspozycja do właściwego działania; usprawnienie bytu jako podmiotu działania do wykonywania aktów odpowiadających jego naturze; Cnoty i wady, w: Stownik przewodnik filozoficzny, s. 373; J. Jaśtal, Etyka i czas. Wariacje aretologiczne, Kraków 2015, s. 20, 25; A. Lekka-Kowalik, Cnota, w: Encyklopedia aksjologii pedagogicznej, s. 168, 169; A. MacIntyre, Dziedzictwo cnoty. Studium z teorii moralności, przet. A. Chmielewski, Warszawa 1996. 
tego myśliciela, posłużono się metodami hermeneutycznymi - pól semantycznych oraz interpretacji wstępnej, zasadniczej, skoordynowanej i kontekstowej ${ }^{13}$.

\section{Znaczenie dokonań mistrza Wincentego - kontekst historyczny}

We Wstępie do dzieła Kadłubka Marzena Matla-Kozłowska pisze:

Kronika mistrza Wincentego Kadłubka to drugie [po Anonimie zwanym Gallem - A. Ż.] z kolei wybitne dzieło, leżące u podstaw polskiej historiografii, pisanej po łacinie, które na długie stulecia miało wywierać [...] wpływ na kolejne utwory dziejopisarstwa polskiego oraz sposób postrzegania i interpretowania początków dziejów polskich. [...] Kronika Mistrza Wincentego jest [...] pomnikiem historiografii i pomnikiem literatury polskiego stulecia XII lub [...] początków XIII ${ }^{14}$.

Kronika ta bez wątpienia stanowi pewnego rodzaju fundament etyki polskiej, w tym etyki pedagogicznej, o czym świadczą nawiązania kronikarza do wartości moralnych oraz cnót, a także liczne zachęty do ich praktykowania przez człowieka. Można ją uznać za klasyczny przykład historiografii pragmatycznej zmierzającej do przekazania nie tylko określonego przesłania moralnego, lecz również wzorców postępowania dzięki uwypukleniu postaw ludzi zasługujących na powszechny szacunek, w tym wypadku - postaw dzielności i męstwa.

Dzieło krakowskiego kronikarza jest, jak twierdzi Jerzy Korolec, typowym produktem epoki, silnie powiązanym z ówczesnymi koncepcjami władzy idealnej, tworzonymi w ramach osobnego gatunku pisarstwa, literatury określanej mianem specula principis, czyli zwierciadła władców ${ }^{15}$. Do zasadniczych

13 J. Grondin, Wprowadzenie do hermeneutyki filozoficznej, przeł. L. Eysień, Kraków 2007; B. Milerski, Hermeneutyka pedagogiczna. Perspektywy pedagogiki religii, Warszawa 2011; Wartość i sens. Aksjologiczne aspekty teorii interpretacji, red. A. Tyszczyk, E. Fiały, R. Zajączkowski, Lublin 2003; A. B. Stępień, Wstęp do filozofii, Lublin 2001; A. Przyłębski, Hermeneutyka. Od sztuki interpretacji do teorii i filozofii rozumienia, Poznań 2019.

14 M. Matla-Kozłowska, Wstęp do Kroniki polskiej Mistrza Wincentego Kadłubka, w: Mistrz Wincenty Kadłubek, Kronika polska, s. v.

15 J. Korolec, Ideał władcy w Kronice mistrza Wincentego, w: Pogranicza i konteksty literatury polskiego średniowiecza, red. T. Michałowska, Wrocław 1989, s. 71-87. 
celów kroniki wyznaczonych przez jej autora należały reguły: „złote ojczy-

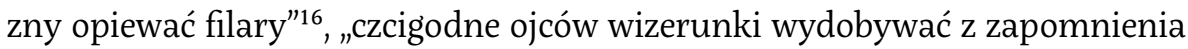
i rzeźbić w kości słoniowej” ${ }^{17}$, „rozwiesić kagańce boskiego światła w zamku królewskim"18. Zawarta w dziele Kadłubka problematyka natury ludzkiej, optymalnego porządku społecznego, odpowiedniego stosunku do przodków i przemijalności pokoleń ujawnia konsekwencję pouczenia moralnego, które można uznać zarazem za doskonały wykład scholastyczny i skarb kultury znacząco wzbogacający pod względem etycznym, kształcącym, wychowawczym i społeczno-politycznym współczesnych ludzi.

Strukturę kroniki tworzą cztery księgi. Pierwsza dotyczy okresu od czasów najdawniejszych do 1202 r. (z aluzjami do 1205 r.), czyli do przejęcia władzy przez Piastów, i opiera się na wątkach podaniowych, w których historycy wyróżniają cykl przekazów krakowskich i wielkopolskich (gnieźnieńskich). Księga druga obejmuje panowanie pierwszych Piastów do początku XI w. - a ściślej do konfliktu Bolesława Krzywoustego ze Zbigniewem - i relacje w niej opierają się na wydarzeniach podanych w kronice Galla (do 1113 r.). W księdze trzeciej, w której opis doprowadzony został do $1173 \mathrm{r}$., Wincenty Kadłubek skorzystał w znacznej mierze z tradycji ustnej, choć nie wyklucza się jego znajomości polskich dokumentów. Ostatnia, czwarta księga, podaje charakterystykę czasów mu współczesnych od początku panowania w Krakowie Mieszka III Starego, a więc zawarte w niej dane i zdarzenia zostały poparte własnymi obserwacjami kronikarza ${ }^{19}$.

Od XIII w. kronika Wincentego Kadłubka była podstawowym źródłem historii ojczystej dla późniejszych pisarzy i dziejopisarzy. Powstawały zarazem liczne kopie i uzupełnienia. Przyjmuje się, że korzystali z niej wykładowcy Akademii Krakowskiej oraz nauczyciele szkół katedralnych, kolegialnych i parafialnych. Pierwsze wydania kroniki z lat 1612, 1712, 1749 pozwoliły nieco upowszechnić to niezwykłe dzieło. Do dzisiaj zachowała się ona w około 30 rękopisach ${ }^{20}$. Niektó-

16 B. Kürbis, Przedmowa, w: Myśli i nauki Mistrza Wincentego zwanego Kadłubkiem, zebr. i przeł. B. Kürbis, Warszawa 1980, s. 8.

17 Tamże. Warto zaznaczyć, że „kością słoniową” autor nazywa tworzywo języka, o którego wysokiej jakości świadczą zwłaszcza piękny styl i drogocenna myśl.

18 Tamże, s. 8.

19 M. Matla-Kozłowska, Wstęp do Kroniki polskiej Mistrza Wincentego Kadłubka, s. VII, VIII. 20 Tamże, s. XIII. 
rzy historycy uznają kronikę Kadłubka również za traktat polityczny i moralitet ${ }^{21}$.

Prymas Polski Stefan Wyszyński, akcentując walory pedagogiczne i humanistyczne tego dzieła, tak stwierdził:

Kronikę można nazwać [...] pedagogiką katolicką, narodową. Ma ona przecież charakter wybitnie nauczycielski. Autor jej stawia sobie jako cel uczyć cnoty, zwłaszcza miłości do ojczyzny [...], dziejów ojczystych, zachęcać do czynów rycerskich, do czynów wzniosłych. Czegoś równie [...] żarliwego nie znajdujemy w piśmiennictwie polskim, bodajże dopiero w Kazaniach sejmowych Piotra Skargi. Jest to księga [...] niezwykła, bo [...] pełna [...] przedziwnego optymizmu, jakiegoś głębokiego szacunku dla dziejów narodu ${ }^{22}$.

Opisując kronikę w sposób zwięzły, nie sposób pominąć specyfiki epoki, w której kształtowały się umysł i mentalność kronikarza. Do stulecia tego stosuje się określenie „renesans XII wieku” ${ }^{23}$, ponieważ wówczas nastąpił dynamiczny rozkwit kultury przejawiający się intensywnym korzystaniem z dziedzictwa antyku, początkami uniwersytetów, powstawaniem szkół i bibliotek, rozwojem literatury i innych dziedzin wiedzy, np. filozofii czy prawa. Nie należy również zapominać o przemianach politycznych umacniających władzę papieską. Ujawniają to zwłaszcza pontyfikaty Aleksandra III i Innocentego III z zauważalną hegemonią Kościoła ${ }^{24}$. „Kronikarz był świadkiem rozbicia dzielnicowego i końca iluzji o wspólnocie rodu Piastów. Za jego życia [...] przybrały na sile walki o władzę między pretendentami do tronu cesarstwa rzymskiego na zachodzie Europy"25.

21 B. Kürbis, Jak Mistrz Wincenty pisał historię Polski, w: Mistrz Wincenty Kadłubek. Człowiek i dzieło, pośmiertny kult i legenda, red. K. R. Prokop, Kraków 2001, s. 76.

22 K. Świżek ocist., Błogosławiony Wincenty Kadłubek. Życie - kult - modlitwy, Jędrzejów 1999, s. 69.

23 Z. Kuksewicz, Zarys filozofii średniowiecznej. Filozofia łacińskiego obszaru kulturowego, Warszawa 1973, s. 11; J. Sulowski, Elementy filozofii XII wieku w Kronice mistrza Wincentego, „Studia Źródłoznawcze”, 20 (1976) s. 19-21.

24 M. Matla-Kozłowska, Wstęp do Kroniki polskiej Mistrza Wincentego Kadłubka, s. IX.

25 H. Samsonowicz, Sytuacja polityczna Polski w czasach Wincentego, w: Onus Athlanteum. Studia nad Kroniką biskupa Wincentego, red. A. Dąbrówka, W. Wojtowicz, Warszawa 2009, s. 29; P. Wiszewski, Polska w kronice Mistrza Wincentego. Ze studiów nad terminologią dzieła i hierarchiami wartości w Polsce pełnego średniowiecza, w: Onus Athlanteum. Studia nad Kronika biskupa Wincentego, s. 75-90. 
$\mathrm{Na}$ takim zatem tle kształtowały się poglądy mistrza Wincentego, który nie był z zamiłowania historykiem, lecz miłośnikiem ksiąg i człowiekiem odpowiedzialnie wykonującym zlecone mu przez Kazimierza Sprawiedliwego zadanie - nie tyle zarejestrowanie czynów przodków: królów i książąt, ile - napisanie traktatu zawierającego wydarzenia z przeszłości oraz myśl przewodnią ${ }^{26}$.Zamysł kompozycyjny Mistrza Wincentego, by w Kronice polskiej opowiadać o przeszłości, przyjmując konwencję referowania tego, co się kiedyś usłyszało od dostojnych starców, wyraźnie nawiązuje do tradycji platońskiej. Odwoływanie się do tradycji oraz cenienie tego, co ma za sobą autorytet dawnych wieków, jest w kronice uderzające ${ }^{27}$.

Właściwa interpretacja treści dzieła Kadłubka nie wydaje się możliwa bez wglądu na wiodące wątki biograficzne ${ }^{28}$ wiążące się z powstaniem kroniki. Wincentego, który urodził się około 1150 r. prawdopodobnie w jednej z miejscowości - Kargów pod Stopnicą lub Karwów koło Opatowa - od XV w. zwano Kadłubkiem. Miano to stanowi archaiczny patronimik i oznacza „syn Kadłuba”, „kadłub” zaś to „wydrążony pień drzewa”. Przezwisko odnosiło się prawdopodobnie nie tyle do ojca, ile do wcześniejszego przodka Wincentego Kadłubka. Wincenty - pierwszy polski kronikarz, myśliciel, kancelista, kapelan nadworny Kazimierza II Sprawiedliwego - pochodził z możnego małopolskiego rodu rycerskiego. Po ukończeniu krajowej szkoły katedralnej w Krakowie udał się na studia zagraniczne. Otrzymał wykształcenie wyższe - stopień magistra, tj. mistrza i został, prawdopodobnie w Paryżu, bądź w Bolonii, absolwentem Studium Generale. Figuruje on z tą godnością na dokumencie z 1189 r. Po powrocie do kraju nauczał przez pewien czas w szkole katedralnej na Wawelu, a następ-

26 M. Matla-Kozłowska, Wstęp do Kroniki polskiej Mistrza Wincentego Kadłubka, s. X; J. Wyrozumski, Kraków i Małopolska w czasach Mistrza Wincentego Kadłubka, w: Mistrz Wincenty Kadłubek. Człowiek i dzieło, pośmiertny kult i legenda, s. 13-19; J. Bieniak, Mistrz Wincenty w życiu politycznym Polski przełomu XII i XIII wieku, w: Mistrz Wincenty Kadłubek. Człowiek i dzieło, pośmiertny kult i legenda, s. 21-48.

27 J. Mańkowski, Krak, uczeń Sokratesa (glosa do Kadłubka Chronica Polonorum I 5,3), w: Inspiracje platońskie literatury staropolskiej. Materiały z konferencji zorganizowanej przez Zespół Badań Literackich nad Historia Kultury Epok Dawnych Instytutu Literatury Polskiej Uniwersytetu Warszawskiego 14-15 października 1998 r., red. A. Nowicka-Jeżowa, P. Stępień, Warszawa 2000, s. 149.

28 O znaczeniu biografistyki: Przedmiot, źródła i metody badań $w$ biografii, red. R. Skrzyniarz, L. Dziaczkowska, D. Opozda, Lublin 2016; Badanie biografii: źródła, metody, konteksty, red. R. Skrzyniarz, E. Krzewska, W. Zgłobicka-Gierut, Lublin 2014. 
nie pracował w kancelarii książęcej Kazimierza Sprawiedliwego, przebywając na dworze do śmierci księcia ${ }^{29}$.

Kazimierz Sprawiedliwy zaskarbił sobie łaski biskupa krakowskiego Wincentego tym, że „pęta niewoli potargał, jarzmo poborów uciążliwych skruszył, podatki częścią zniósł, ciężary nie tylko zmniejszył, ale nawet zupełnie usunął, musy i przymusy do szczętu zniweczył’30. Kronikarz cenił księcia za przychylne nastawienie do ludzi oraz za umiejętności polityczne. Uosabianie cnót kardynalnych (roztropności - prudentia, męstwa - fortitudo, umiarkowania - temperantia i sprawiedliwości - iustitia) oraz cnót teologalnych (wiary - fides, nadziei-spes, miłości - charitas) pozwalało mu wzorcowo sprawować władzę w państwie, zyskując szacunek oraz zaufanie podwładnych. W ocenie Kazimierza kronikarz zaakcentował motyw umiłowania cnót, porządku, spokoju i harmonii. Na taki model władzy niewątpliwy wpływ miał obowiązujący wówczas etos rycerski ${ }^{31}$.

Jako kronikarz skłaniał się ku refleksji etycznej, zwłaszcza nad pojęciem sprawiedliwości. Był rzecznikiem nowych stosunków politycznych w Polsce XII w. Podkreślał również wychowawcze znaczenie dziejów narodu i państwa polskiego. Następnie objął funkcję prepozyta przy kolegiacie sandomierskiej. Godność proboszcza piastował do 1207 r. Dzięki powiązaniom z obozem reformatorów Kościoła otrzymał nominację w 1208 r. na biskupa krakowskiego, a w 1764 r. został beatyfikowany, czyli zaliczony w poczet błogosławionych. Jako przykładny chrześcijanin był zwolennikiem silnej władzy księcia, pod warunkiem troski o dobro Kościoła i duchowieństwa oraz podporządkowania się prawom kościelnym. Zaliczano go do zwolenników przyznania duchownym, głównie biskupom, prawa i obowiązku upominania monarchów, a także występowania w obronie uciskanych poddanych. Należał do ludzi dbających o swoją diecezję, hojnych, o czym świadczą liczne darowizny, np. przypisuje się mu ufundowanie grobowca św. Stanisława w katedrze wawelskiej. W 1218 r. zrzekł

29 Kadłubek Wincenty, w: Słownik przewodnik filozoficzny, s. 146-147; M. Matla-Kozłowska, Wstęp do Kroniki polskiej Mistrza Wincentego Kadłubka, s. v, vi; B. Kürbis, Przedmowa, s. 10; K. R. Prokop, Wincenty Kadłubek, Kraków 2005, s. 14; K. Świżek ocist., Błogosławiony Wincenty Kadłubek, s. 13-53.

30 P. Jasienica, Polska Piastów, Warszawa 1985, s. 116.

31 R. Bubczyk, Kazimierz Sprawiedliwy - władca idealny mistrza Wincentego („Chronica Polonorum"), „Kwartalnik Historyczny", 116 (2009) nr 1, s. 36, 37; T. Michałowska, Szkice mediewistyczne, s. 169, 170. 
się jednak godności biskupiej. Przypuszczalnie ciążyła mu konieczność administrowania diecezją oraz stały udział w życiu publicznym, ponieważ zamiłowania skłaniały go raczej ku skromnemu życiu klasztornemu i studiowaniu nauk. Osiadł więc w klasztorze cystersów w Jędrzejowie kieleckim pierwotnie noszącym nazwę Brzeźnicy. Czy był tam tylko rezydentem, czy też złożył śluby zakonne - historycy nie mają pewności. Tradycja cysterska opowiada się jednak za tą drugą wersją ${ }^{32}$.

Wincenty Kadłubek zmarł w 1223 r. w Brzeźnicy. Ciało, prawdopodobnie zgodnie z jego wolą, zostało złożone w świątyni opactwa w Jędrzejowie, w osobnym grobie w prezbiterium. W 1764 r. Kongregacja Obrzędów zatwierdziła kult Wincentego, a tydzień później decyzję tę potwierdził papież Klemens XIII. W katedrze wawelskiej wzniesiono ołtarz z obrazem włoskiego malarza, który przedstawiał Błogosławionego w habicie cysterskim u stóp Matki Bożej. $\mathrm{Z}$ kolei kaplica bł. Wincentego Kadłubka znajduje się przy kościele św. Wojciecha w Krakowie ${ }^{33}$. I dziś postać tą otacza się kultem, obchodząc jubileusze jej urodzin, przybycia do klasztoru cystersów, śmierci oraz beatyfikacji, a także uroczystości odpustowe i nabożeństwa ku czci bł. Wincentego w sanktuarium jędrzejowskim. Relikwie znajdują się natomiast w katedrze sandomierskiej. O autorytecie, jakim cieszy się ten niezwykły Polak, świadczą również liczne prace artystyczne ${ }^{34}$ oraz naukowe zainspirowane jego działalnością oraz przesłaniem intelektualnym i duchowym.

32 M. Matla-Kozłowska, Wstęp do Kroniki polskiej Mistrza Wincentego Kadłubka, s. VI, VII, X; B. Kürbis, Przedmowa, s. 10; K. R. Prokop, Wincenty Kadłubek, s. 45-49; R. Grodecki, Mistrz Wincenty, biskup krakowski (zarys biograficzny), „Rocznik Krakowski”, 19 (1923) s. 30-61; K. Chmielewska, Uczeni w średniowiecznych klasztorach. Wyksztatceni zakonnicy $-w$ relacjach kronikarskich, w: Uczeni z odległej i nieodległej przeszłości. Rekonstrukcje, interpretacje, refleksje, red. A. Żywczok, M. Kitlińska-Król, Katowice 2019, s. 35-46.

33 K. Świżek ocist., Błogosławiony Wincenty Kadłubek, s. 54-93; M. Matla-Kozłowska, Wstęp do Kroniki polskiej Mistrza Wincentego Kadłubka, s. VI, VII, X; B. Kürbis, Przedmowa, s. 10; K. R. Prokop, Wincenty Kadłubek, 45-49; M. Plezia, Mistrz Wincenty zwany Kadłubkiem, w: Pisarze staropolscy, sylwetki, t. 1, red. S. Grzeszczuk, Warszawa 1991, s. 93-131; P. Jasienica, Trzej kronikarze, Warszawa 1992, s. 315-411.

34 J. Samek, Błogosławiony Wincenty Kadłubek w sztuce (rozeznanie problemu), w: Mistrz Wincenty Kadłubek. Człowiek i dzieło, pośmiertny kult i legenda, s. 93-101. 


\section{Specyfika odwagi, dzielności i męstwa oraz ich przeciwieństw}

Wincenty Kadłubek, chcąc przybliżyć specyficzne cechy odwagi jako postawy, dokonał opisu postępowania ludzi, których:

nie ponaglała [...] żądza panowania, ani namiętność posiadania, lecz siła dojrzałej odwagi była ich żywiołem, iż poza wielkodusznością nic nie uważali za wielkie i przyrostowi swojej dzielności nie stawiali nigdy żadnych granic. Nie byłaby to bowiem dzielność, gdyby chcieli ją zamknąć w ciasnym więzieniu ${ }^{35}$.

Autor ukazuje dzielność pod postacią cnoty stopniowalnej, co oznacza, że w jego przekonaniu istnieje mała/mniejsza bądź wielka/większa dzielność. Dzielność wyraża się jednak najlepiej w optimum cnoty i tylko jako taka może być zidentyfikowana.

Cnotą tą wyróżnia się człowiek, który gotów jest po pierwsze - narazić się na niebezpieczeństwo (aggredi pericula), po drugie - znosić przykrości (sustinere mala) dla słusznej sprawy, np. dla zwycięstwa prawdy czy sprawiedliwości. Mężnych należy poszukiwać nie tylko na polach bitewnych, lecz również wśród przykładnych członków rodzin, w salach szpitalnych, w obozach koncentracyjnych, w miejscach zesłania ${ }^{36}$. Łatwo też daje się rozpoznać współczesne odpowiedniki męstwa w postawie śmiałej bezkompromisowości, autentyczności czy obiektywizmu jako rezygnacji ze stronniczości, a przeciwieństwa - w nadmiernej „dyplomatycznej” nieszczerości czy stosowaniu ingracjacji.

Za zasadnicze przeciwieństwo dzielności Kadłubek uznaje bojaźliwość (inaczej - strachliwość, płochliwość), pisząc: „Nieprzyjazna jest [...] dzielności bojaźliwość [...]. Żadna to bowiem dzielność, skoro bojaźliwa [...]. Co więcej, skoro nie ma żadnej sposobności do ćwiczenia odwagi”37. Przeszkodami w realizowaniu dzielności pozostają więc strach, lęk, nadmiar obaw, niepokoju, rozterek, a przede wszystkim - brak okazji do doskonalenia się w cnocie dzielności, czyli do jej systematycznego trenowania.

35 Mistrz Wincenty Kadłubek, Kronika polska, s. 8.

36 Jan Paweł II, Cnota męstwa. Przemówienie na audiencji ogólnej 15 XI 1978, w: Jan Paweł II, Nauczanie społeczne 1978-1979, Warszawa 1982, s. 45.

37 Mistrz Wincenty Kadłubek, Kronika polska, s. 14. 
Średniowieczny kronikarz wyraźnie odróżnia odwagę od zaciekłości (inaczej - zawziętości manifestującej się w agresywnej nieustępliwości), pisząc: „Chwalę odwagę, zaciekłości nie pochwalam, chyba że coś popełniono z gorliwego starania o sprawiedliwość, a nie z uczucia nienawiści lub [...] pychy"38. Odwaga nieskazitelna pod względem etycznym pozostaje bowiem daleka od nienawiści i pychy, bliska zaś gorliwej sprawiedliwości. Respektowanie zasady sprawiedliwości $\mathrm{w}$ relacjach społecznych wymaga więc poszanowania takiej wartości jak odwaga, która realizuje się dzięki cnocie dzielności bądź męstwa.

Zalecane przez mistrza Kadłubka łączenie odwagi z ostrożnością (która „skłania do oględności, oględność rodzi ufność, a ufność daje życie odwadze, dzięki której człowiek sam siebie w śmiałości przewyższa"39) bynajmniej nie oznacza zachęty do przejawiania tchórzostwa, lecz raczej - zawołanie do konsolidacji wewnętrznej, do samodyscypliny, skupienia na celu, ufności w zwycięstwo i przekraczania siebie w reprezentowanej postawie. Odwaga wynikająca z miłości ojczyzny ujmowana jest w tym wypadku jako gotowość poświęcenia swego życia, by położyć kres nieszczęściom publicznym, niewoli lub nieustannej wojnie. W trakcie walki kronikarz proponuje pamiętać „nie tyle o rycerskiej dziarskości w każdym wypadku [...], ile o karności" ${ }^{40}$. Przypomina w ten sposób, że odwaga nie powinna przybierać postaci brawury, lecz wiązać się raczej z samodyscypliną, a czasem także z rozważnym posłuszeństwem wykluczającym zuchwałość. Dlatego większej odwagi może wymagać współcześnie pomoc udzielana przez misjonarza ludności afrykańskiej, niż choćby zdobycie przez himalaistę Mont Everestu.

Podsumowując tę część rozważań, należy zauważyć, że odwaga, tzw. dojrzała, przejawia się w optymalnej mierze cnoty dzielności, i tylko tę przedkłada Kadłubek uwadze czytelników swego dzieła. Zasadniczym przeciwieństwem dzielności jest bojaźliwość, czyli tchórzostwo. Odwaga, dzielność i męstwo są, jego zdaniem, nietożsame z zaciekłością i zawziętością, które wynikają z nienawiści i pychy, a także z zuchwałości, dziarskości oraz brawury.

38 Tamże, s. 121.

39 Tamże, s. 97.

40 Tamże, s. 135 . 


\section{„Geneza” odwagi oraz jej związki z innymi wartościami i cnotami}

Ontycznych „początków” odwagi Kadłubek proponuje poszukiwać w kluczu terminologicznym o nazwie „dusza”, gdyż jest przekonany, że nie tyle ludzkie ciało, ile „dusza podsyca działanie odwagi" ${ }^{41}$. W kulturze średniowiecza życie duchowe jawiło się ludziom nie jako próżne pragnienie czy też idea oderwana od realiów. Stanowiło życie w pełnym tego słowa znaczeniu, wzorzec zorganizowanego postępowania, wcielony w określony organizm społeczny, np. w formy instytucjonalne ${ }^{42}$. Z powodzeniem daje się więc na tej podstawie stwierdzić, że uduchowienie człowieka sprzyja postawie odwagi, a także, że odwaga stanowi istotny przejaw tegoż procesu uduchowienia, niejako jego zwieńczenie.

Jako egzemplifikację słowiańskiej odwagi kronikarz przywołuje człowieka wyróżniającego się zapałem do jej ćwiczenia, który:

wolał raczej sam cierpliwie znosić braki niż potrzebującemu odmawiać pomocy lub nie wynagradzać dobrze zasłużonych. A i nie brakło mu trzeźwości, która jest siostrą uczciwości, przyjaciółką roztropności [...]. Gorliwiej dbał o to, żeby podobać się więcej z przymiotów umysłu niż ciała ${ }^{43}$.

Cenił bowiem ludzi „sławnych z dzielności rycerskiej nie mniej niż z pobożności" ${ }^{44}$.

We fragmentach tych nietrudno trafić na potwierdzenie związku odwagi jako wartości (i dzielności czy męstwa jako cnót) z innymi wartościami i cnotami, np. z uczciwością, roztropnością oraz pobożnością. Zresztą, akty odwagi można zinterpretować również jako główne przejawy ludzkiej uczciwości, roztropności, a także bogobojności. Oprócz tego mistrz twierdzi, że „Cierpliwość [...] jest córą Dzielności"45, a zatem i kolejne powiązanie - dzielności z cierpliwością można uznać za trafne. Problematyka ta dowodzi dostrzegania przez Kadłubka współwystępowania określonych wartości i cnót, a może nawet współzależności zarówno między wartościami, jak i między cnotami. Opis relacji tego typu

\footnotetext{
41 Tamże, s. 11.

42 Ch. Dawson, Szkice o kulturze średniowiecznej, s. 78.

43 Mistrz Wincenty Kadłubek, Kronika polska, s. 28, 29.

44 Tamże, s. 81.

45 Tamże, s. 191.
} 
stanowi treść polskiej historiografii średniowiecznej i pod tym względem z pewnością tworzy podstawy współczesnej etyki.

Miłość ojczyzny, a przede wszystkim konieczność jej obrony, wyzwala w obywatelach męstwo realizowane w walce. Męstwo nie oznacza nieodczuwania strachu, lecz jego zminimalizowanie w określonym celu oraz zapanowanie nad nadmierną śmiałością wynikającą już z nierozwagi. W realizacji cnoty męstwa istotne okazują się dwa czynniki: wytrwałość bądź wytrzymałość w określonej sytuacji, np. zagrożenia, oraz ofensywa, np. gdy tylko zapanują okoliczności sprzyjające pokonaniu przeszkody ${ }^{46}$. Kadłubek wspomina o męstwie w następujących słowach:

Czego podejmujemy się z miłości ojczyzny, miłością jest, nie szaleństwem, męstwem, nie zuchwałością; bo mocna jest miłość jak śmierć, im trwożliwsza, tym śmielsza. Nic bowiem śmielej nie wzywa obywateli pod broń niż obawa przed ogólnym niebezpieczeństwem [...]. Cóż tedy pobudziło Machabeusza, mającego ośmiuset mężów przeciwko dwudziestu dwom tysiącom Bakchidesa, iż zapomniawszy o sobie pamiętał raczej o swoich ziomkach niż o własnym życiu. Miłość ojczyzny. Dlaczego syn Saula, gdy stracił na półmorgowym skrawku [ziemi] dwudziestu mężów, z jednym tylko towarzyszącym mu giermkiem uderzył na tyle zastępów filistyńskich i popłoch sprawił? ${ }^{47}$

Do tych zwycięstw bez wątpienia przyczyniło się męstwo żołnierzy jako cecha sprzyjająca pokonywaniu nie tylko przeciwności związanych z toczącą się wojną, lecz także innych przeszkód zewnętrznych, np. przyrodniczych, społeczno-politycznych, oraz przeszkód wewnętrznych, np. fizycznego bądź psychicznego zmęczenia organizmu, choroby.

Kadłubek dokonuje opisu prawidłowej postawy obywatela nie tylko w obliczu zagrożenia ojczyzny, lecz także w warunkach ucisku, wyzysku i innych form prześladowania, opisu będącego jednocześnie apelem, by w takich okolicznościach ucieleśniać męstwo ostatecznie prowadzące do zwycięstwa:

46 J. Zabielski, Roztropność, męstwo, umiarkowanie i sprawiedliwość jako wyznaczniki chrześcijańskiej moralności. Studium tomistyczno-aksjologiczne, Warszawa 2015, s. 50, 53.

47 Mistrz Wincenty Kadłubek, Kronika polska, s. 96-97. 
Mężniej [...] towarzysze broni, mężniej! Ten dzień, który zaświtał w blaskach chwały, ciągle jaśnieje sławą wypróbowanego męstwa, pogodniejszy jest w południe i nie zna zachodu. Uciskają nas? Męstwo właśnie w uciśnieniu [ucisku - od autorki] zbiera siły, [...] je rozwija, [...] wypróbowuje. Przygniatają? Pień palmy tym wyżej wyrasta, im bardziej jęczy korzeń większym przygnieciony ciężarem. Uderzają? Tak zwiększa się stałość. Przekonano się bowiem, że od wstrząsu umacniają się kolumny, a plewy oddzielają od ziarna. Depczą? Taka jest natura winogron, że całe nie mają kwasu, natomiast udeptane w tłoczni nabierają cierpkiego smaku. Jednakże dlaczegóż uciekamy? Mylę się mężowie, nie uciekamy, lecz nieprzyjaciel [nas] ściga. Dokąd, mężowie, dokąd? Zwyciężamy, towarzysze, nie nas zwyciężają ${ }^{48}$.

Reasumując, wypada tu zaakcentować, że Wincenty Kadłubek „rodowód” odwagi odnajdował w uduchowieniu człowieka oraz w miłości ojczyzny wyzwalającej w obywatelach siły do jej obrony. Wysunął stosowne argumenty na potwierdzenie związku odwagi jako wartości (i męstwa czy dzielności jako cnót) z innymi wartościami oraz cnotami, takimi jak uczciwość, roztropność, cierpliwość, wielkoduszność i pobożność.

\section{Odwaga jako przejaw przezwyciężenia strachu, lęku, niepokoju, nihilizmu}

Pycha i chciwość jednostek pozbawionych wewnętrznego spokoju prowadzą do niepokoju społecznego określanego terminem „wojna”. O osobowościowych przyczynach wojny kronikarz pisze: „zadufany w [swoje] wyjątkowe uprzywilejowanie, niestety, pod wpływem pewnej beztroskiej zarozumiałości popadł w jakąś nieoględną gnuśność. Nie ma bowiem [...] spokoju, a jeśliby nawet był, króciutko trwa i pogodną swą ciszą zwiastuje bliską burzę"49. Gnuśność została ukazana w dziele Kadłubka jako cecha utrudniająca ukształtowanie się i przejawianie dzielności. Współcześnie dyskusję nad gnuśnością podjął m.in. Marcin Zdrenka ${ }^{50}$.

48 Tamże, s. 154.

49 Tamże, s. 177.

50 M. T. Zdrenka, O gnuśności: studium lenistwa i jego kontekstów, Toruń 2012. 
Odnośnie do przezwyciężania strachu i lęku w trakcie działań wojennych, decydentom zwlekającym przy rozwiązaniu istotnej kwestii społecznej bądź wahającym się, mistrz słusznie radzi:

Nie godzi się, aby w sprawie tak oczywistej wahał się wasz rozum. Któż by wątpił, że korzyść wielu okupuje się kosztem niewielkiej straty? [...] Któż by nie wiedział, że trzeba wybrać mniejsze zło, zwłaszcza gdy pożytek publiczny należy przedłożyć nad własny ${ }^{51}$.

Uzupełnia tę myśl wyjaśnieniem, że „Równowaga rozumu nie znosi, aby zdrowy umysł sprzeciwiał się i wadził z samym sobą"52. A następnie sugestywnie zachęca: „Śmiało ruszaj, nie bój się! Od ciebie zależy twoje ocalenie!”53 Ukształtowanie cnoty dzielności bądź poddanie się jej przeciwieństwu - tchórzostwu - Kadłubek pozostawia pod rozwagę człowiekowi, jego indywidualnej decyzji. W budzeniu odwagi na polu bitwy kronikarz dostrzega także znaczenie silnej woli i - jak współcześnie nazwalibyśmy - autodeterminacji.

Strach może niejednokrotnie odebrać odwagę cywilną osobom pozostającym w warunkach zagrożenia, ucisku, prześladowania. Szczególnie poszukiwani są wtedy ludzie zdolni do przekroczenia tzw. bariery lęku. Aby zdobyć się na męstwo, człowiek musi wpierw przyjąć na siebie ryzyko nowej sytuacji, narażenia się na przykre konsekwencje, krzywdy czy straty materialne. Dlatego na wezwanie do męstwa odpowiadają tylko niektórzy, silnie miłujący prawdę, dobro, sprawiedliwość. Cnota męstwa wymaga więc przekraczania własnych słabości, a niekiedy nawet poświęcenia ${ }^{54}$.

Oprócz odwagi koniecznej do podjęcia walki zbrojnej (którą kronikarz opisał we fragmencie: „dla dzielnego męża milsze są udręki wygnania niż domowe rozkosze" ${ }^{\prime 5}$ ), czyli odwagi niezbędnej towarzyszom broni, Kadłubek uwzględnił również heroiczną postawę człowieka, który „walczy bez wojny, zwycięża

51 Mistrz Wincenty Kadłubek, Kronika polska, s. 264.

52 Tamże, s. 268.

53 Tamże, s. 265.

54 Jan Paweł II, Cnota męstwa. Przemówienie na audiencji ogólnej 15 XI 1978, s. 46; tegoż, Wezwanie do męstwa. Przemówienie na konsystorzu publicznym 30 VI 1979, w: tegoż, Nauczanie spoteczne 1978-1979, s. 117-119.

55 Mistrz Wincenty Kadłubek, Kronika polska, s. 143. 
bez bitwy" ${ }^{\prime 6}$, tzn. usilnie zabiega o pokojowe rozwiązywanie konfliktów oraz nienarażanie swego narodu na straty materialne i duchowe w wyniku działań wojennych. Dzielność zapewniająca takie rozstrzygnięcia nie jest pod względem jakościowym mniej znacząca, a wręcz przeciwnie - równie doniosła jak dzielność bitewna, zwłaszcza, gdy wojna okazuje się zbyteczna. Taką postawę wobec wojny wyrażają słowa:

[...] przepadło bitne wojsko! Tak zmarniała w niedorzecznej wojnie dzielność wspaniałych rycerzy! Wymowa najwymowniejszych nie starczyłaby, żeby chociaż powierzchownie napomknąć, a cóż dopiero szerzej opowiedzieć o ich imionach, osobach, szlachetnym pochodzeniu, rodowodzie, o godnościach, dzielności, skrzętności, dostatkach! Aż po dziś dzień różni ludzie na różne sposoby ich opłakują ${ }^{57}$.

Najtragiczniejszym skutkiem wojny, w przekonaniu autora, jest jednak utrata ludzi szlachetnych i dzielnych, którzy stanowią największy skarb oraz gwarancję bezpieczeństwa, czyli przetrwania narodu. Taki rodzaj straty należy do nieodwracalnych. Koszt wojny jest zbyt wysoki w stosunku do zapowiedzi zysku terytorialnego bądź innego, np. materialnego, choćby zdobycia łupów wojennych.

Człowiek potrafiący zachować wewnętrzny spokój - zdaniem kronikarza bywa zazwyczaj niechętny wobec wszczynania wojen, dlatego zarówno ludzi jednomyślnych, jak i niejednomyślnych „łaskawym przygarnięciem zaprasza do trwałego pokoju" ${ }^{58}$, a jego „umiarkowanie nakazuje zgodę"59.

Sprawcą zaś tej zgody i więzadłem, złotym łańcuchem zgoła, był mąż w pilnym staraniu o wszelką cnotę, o wszelką wiedzę, o wszelką mądrość [...], wszelką grzecznością obyczajów się wyróżniający, rodu szlachectwem nie mniej niż umysłu nader wybitny - ten sam arcybiskup Piotr ${ }^{60}$. [..] Umiał on surowo karcić winy przestępców i z dobrocią ich powściągać: ani bowiem nie był tak dobry, iżby nie karał, ani tak surowy, żeby zapomniał o dobroci. Tak dalece dzięki połączeniu sprawiedliwości i łagodności

56 Tamże, s. 167.

57 Tamże, s. 171.

58 Tamże, s. 188.

59 Tamże.

60 Tamże, s. 228. 
promieniowała z niego pogoda, jakby z jakiegoś czystego stopu [złota ze srebrem], że ani surowość nie była nieugięta, ani łagodność słaba. Tak żywo współczuł on z cudzym nieszczęściem, że pierwej zapobiegał cudzym krzywdom niż własnym, i dlatego w sprawach ludzi uciśnionych występował nie jako sędzia, lecz jako obrońca ${ }^{61}$.

Człowiek taki „wszystkim okazywał się nadzwyczaj ludzkim”62.

Do przejawiania dzielności i miłosierdzia nakłania także Jan Paweł II: „Bądźcie zawsze gotowi do obrony wobec każdego, kto domaga się uzasadnienia tej nadziei, która w was jest. A z łagodnością i bojaźnią Bożą zachowujcie czyste sumienie (I P 3, 15-16)"63. Z postawą odwagi wiążą się kolejne atrybuty osobowościowe: wrażliwość aksjologiczna i doświadczenie moralne ${ }^{64}$, które umożliwiają zajęcie właściwej postawy wobec winowajców. Połączenie sprawiedliwości i łagodności pozwala częściej przyjmować raczej postawę „obrony” innych ludzi niż ich bezlitosnego osądu. W tym wyraża się również kwintesencja chrześcijańskiego miłosierdzia.

Kadłubek do niewątpliwych zalet miłośnika pokoju zalicza rozległą wiedzę oraz takie cnoty jak mądrość, łagodność, dobroć, sprawiedliwość, wyrozumiałość czy grzeczność (inaczej - uprzejmość). Jest przekonany, że „wśród waśni nie ma miejsca ani dla wierności, ani dla posłuszeństwa i że każda rzeczpospolita lubi spokój, a nie spory"65. Jak znamienne i wciąż aktualne są poglądy mistrza, nie trzeba przekonywać, zważywszy na charakter współczesnego życia zbiorowego, publicznych roszad czy waśni politycznych, i to nie tylko w Polsce, lecz także w innych krajach.

W wyjątkowym przypadku „szczególną chlubą dzielności jest dobrowolnie wyjść aż na spotkanie śmierci"66. Wypowiedź ta rodzi skojarzenia z biografiami postaci, które przywoływał Wincenty Kadłubek: św. Piotra, św. Wojciecha,

61 Tamże, s. 52.

62 Tamże, s. 269.

63 Jan Paweł II, Zachowajcie odwagę i dumę z waszej wiary. Przemówienie w kaplicy ambasady włoskiej w Ankarze 29 XI 1979, W: Jan Paweł II, Nauczanie społeczne 19781979, S. 377 .

64 U. Ostrowska, Doświadczanie conditio humana przez człowieka współczesnego. W trosce o człowieczeństwo z perspektywy aksjologicznej, Gorzów Wielkopolski 2020, s. 156.

65 Mistrz Wincenty Kadłubek, Kronika polska, s. 264.

66 Tamże, s. 143. 
św. Wawrzyńca, św. Jana, Króla Dawida, Saula, Salomona, ale także ze świętymi współczesnymi, m.in. o. Maksymilianem Kolbe czy ks. Jerzym Popiełuszko. Losy tych świętych stanowią osobliwy wzorzec dzielności wyrażający się właśnie w dobrowolnym wyjściu na spotkanie śmierci, by ocalić godność i przezwyciężyć nihilizm. Celem tego wyjścia nie była jednak śmierć, lecz szczęśliwe życie wieczne. Dyskurs dotyczący męstwa podejmował w swym nauczaniu społecznym również Jan Paweł II, który pisał m.in.:

Dam jeszcze jeden przykład. Człowiek, któremu obiecują wolność a nawet karierę, jeśli zaprzeczy swoim przekonaniom, albo jeżeli zgodzi się na coś, co uwłacza jego uczciwości względem drugich. A on [...] odpowiada „nie”. Mimo pogróżek z jednej, i mimo obietnic z drugiej strony. Człowiek mężny! Wiele jest [...] takich przejawów męstwa, czasem heroicznego, o których nie pisze się w gazetach, o których mało kto wie [...]. Pragnę złożyć hołd tym wszystkim nieznanym z imienia ludziom mężnym! ${ }^{67}$.

To właśnie, że szczególną wagę przywiązują oni do zgodności z własnym sumieniem, czyni ich zarazem mężnymi i godnymi uznania.

Kadłubek, zasadnicze znaczenie dzielności człowieka dostrzega - uogólniając trzecią część analiz - w usuwaniu jej przeciwieństw oraz minimalizowaniu strachu, lęku, niepokoju, nihilizmu na drodze osiągania życia dobrego, tzn. prowadzącego do zbawienia. Nie pomija również udziału dzielności w skutecznej walce ze złem, w przywracaniu pokoju, a także porządku publicznego wynikającego z respektowania zwłaszcza zasad sprawiedliwości i miłości społecznej.

\section{Sugestie wychowawcze dotyczące doceniania odwagi oraz kształtowania dzielności w kolejnych pokoleniach}

Wychowanie do urzeczywistniania wartości jawi się jako szansa wykorzystania zdolności człowieka do życia we wspólnocie, do aktywizowania twórczych zasobów oraz wskazania kierunku osiągania coraz wyższego poziomu człowieczeństwa. Budzi również nadzieję na kreowanie ludzkiego życia oraz realiów społecznych i politycznych według pożądanej hierarchii wartości, w której

67 Jan Paweł II, Cnota męstwa. Przemówienie na audiencji ogólnej 15 XI 1978, w: Jan Paweł II, Nauczanie społeczne 1978-1979, s. 45. 
znajdą się miłość, odpowiedzialność, prawda ${ }^{68}$, a także - w moim przekonaniu odwaga. Dzięki uwewnętrznianiu wartości staje się możliwe nie tylko budowanie odpowiedniej ich hierarchii, ale i uosabianie cnót jako trwałego komponentu ludzkiego charakteru.

Zachętą przyjazną do przejawiania dzielności skierowaną do kolejnych pokoleń, a także do ludzi współczesnych są, w przekonaniu Kadłubka, wzory przodków ${ }^{69}$ - nawet te z najodleglejszych epok, choćby z kultury antycznej. Rodakom poleca, oprócz analizy bohaterów starożytności, poznanie wzorów dzielnych Polaków jak Krak ${ }^{70}$, św. Stanisław, Kazimierz Sprawiedliwy ${ }^{71}$, arcybiskup gnieźnieński Jan Janik, biskup krakowski Pełka. Wiedza tego typu już zapoczątkowuje dobre życia wynikające z kontynuacji ich planu etycznego, zwłaszcza uosabiania cnót. Dopuszczenie dzielnych przodków do głosu ułatwia proces dojrzewania, dzisiaj określany jako dojrzewanie aksjologiczne, u ludzi przejmujących takie wzory, i sprawia, że nawet trudy życia, takie jak poczucie osamotnienia, dają się łatwiej znieść.

Współobecność przodków można uznać za nieocenione towarzystwo w „podróży” - metaforze życia. Potwierdza to fragment Kroniki polskiej:

Wszelkie dowody dzielności [...] odbijają się w przykładach przodków jakby w [...] zwierciadłach. Bezpieczniej bowiem wybrać się w drogę, gdy przodem idzie przewodnik, gdy światło posuwa się przed nami, i wdzięczniejszy jest obraz obyczajów, który obfitująca w przykłady starożytność przepowiada. Pragnąc tedy [...] dopuścić potomnych do udziału w cnotach pradziadów [...], którzy od początku tej drogi czułym sercem sprzyjać mi będą [...] ciężar przestanie być ciężarem i trud niech nie wyda się trudem. W drodze bowiem mile towarzystwo jest jak wóz podróżny ${ }^{72}$.

68 K. Ostrowska, Wychowywać do urzeczywistniania wartości, w: Edukacja aksjologiczna, t. 4: Wybrane problemy przekazu wartości, red. K. Olbrycht, Katowice 1999, s. 33.

69 A. Witkowska, K. Górski, Wzorce ideowe zachowań ludzkich w XII $i$ XIII wieku, w: Polska dzielnicowa i zjednoczona. Państwo, społeczeństwo, kultura, red. A. Gieysztor, Warszawa 1972, s. 119-158.

70 Swoiste novum stanowił w Kronice polskiej opis monarchy jako reprezentanta obywateli, władcy sprawującego rządy na podstawie wszystkich obowiązujących praw; J. Mańkowski, Krak, uczeń Sokratesa (glosa do Kadłubka Chronica Polonorum I 5,3), w: Inspiracje platońskie literatury staropolskiej, s. 147.

71 R. Bubczyk, Kazimierz Sprawiedliwy, s. 31-53.

72 Mistrz Wincenty Kadłubek, Kronika polska, s. 5, 6. 
Porównanie przodków wraz z ich cennym przekazem międzygeneracyjnym do wozu podczas uciążliwej podróży pozwala domyślać się znaczenia antenatów dla potomnych, które wyraża się nie tyle w ułatwianiu, ile w umożliwianiu wartościowego istnienia.

W innym miejscu kroniki Kadłubek zapisał: „Chlubą wszak dzielnego męża, bezrękiego jest dzięki męstwu wydawać się oburękim [oburęcznym - A.Ż.]"73. Oto stwierdzenie, które obecnie mogłoby być wyzwaniem dla ludzi z niepełnosprawnością, zwłaszcza ruchową, by podejmując życiowe zadania wykazywali się męstwem niwelującym niedobory sprawności fizycznej. Dzielność jako komponent ludzkiej psychiki ułatwia im kompensację deficytów i odwraca uwagę otoczenia od ułomności. Uosabianie tej cechy przez ludzi z różnymi typami niepełnosprawności wspiera ich pozytywne postrzeganie, gdyż w ich wizerunek zostaje wpisana samodzielność, zaradność i niezależność, a nawet umiejętność chronienia innych.

Kontynuację tej myśli można dostrzec w stwierdzeniu : „Wolę więc, żeby się nam nie powiodło, niż żebyśmy nie mieli doświadczyć dzielności" ${ }^{14}$. Ujawnia się tu głęboka mądrość autora doceniającego nawet traumatyczne doświadczenia życiowe, takie jak niepowodzenia, porażki i klęski, gdyż te umacniają człowieka w przezwyciężaniu trudności oraz kształtują w nim pożądaną dzielność. Interpretacja ta zgodna jest z kolejną opinią kronikarza: „Dzielność podnieca dzielność, a odwaga ćwiczy odwagę. Szorstka, a nie gładka powinna być osełka do sposobienia dzielności"75. Im zatem więcej okazji do wykazywania się dzielnością, tym większe prawdopodobieństwo utrwalenia się tej cechy w strukturze charakteru danego osoby. Okoliczności temu sprzyjające nie należą zazwyczaj do prostych, lecz właśnie poradzenie sobie w sytuacjach skomplikowanych najskuteczniej formuje dzielność.

Mistrz Wincenty pisze, że „Niemałą szkołą dzielności jest unikanie bezczynności" ${ }^{\prime \prime 6}$, przekonując, że życie czynne - zaangażowanie człowieka w sprawy etycznie nieskazitelne - podsuwa mu sposobność do ćwiczenia dzielności i do doskonalenia się w tej cnocie. Bezczynność, przejawiająca się w niechęci

73 Tamże, s. 94.

74 Tamże, s. 143.

75 Myśli i nauki Mistrza Wincentego zwanego Kadłubkiem, s. 149.

76 Tamże, s. 151. 
do pokonywania przeszkód życiowych oraz przyzwyczajająca do rozleniwienia, rodzi postawy defensywne, czyli rezygnację z ubiegania się w zmaganiach indywidualnych i społecznych o odpowiednie miejsce wartości moralnych. Respekt dla odwagi oraz podejmowanie wysiłku związanego z ujawnianiem dzielności jako cechy charakteru stanowią już symptomy odpowiedniego procesu wychowania moralnego.

Warto więc w edukacji aksjologicznej, ukierunkowanej na kształtowanie postaw wobec wartości i ich systemów, skorzystać zarówno z metody treningu, jak i metody nadawania znaczenia określonym zdarzeniom życiowym, nie zapominając naturalnie o zasadniczej z metod wychowania - modelowaniu. Odpowiednie przygotowanie nauczycieli i pedagogów musiałoby uwzględniać zdobycie kompetencji zarówno w zakresie kształtowania hierarchii wartości młodego pokolenia ${ }^{77}$, jak i nabywania przez wychowanków cnót moralnych świadczących już o umiejętności przekładania wartości na właściwe czyny. Za nadal aktualne może posłużyć zawołanie-apel do kolejnych pokoleń:

Stoisz naprawdę, gdy stojąc upadku się strzeżesz przyczyny; tak to czynem na cnotę zasłużysz, cnotami na czyny ${ }^{78}$.

„Sytuacja upadku” oraz „sytuacja pokusy”, terminy zapożyczone z teologii moralnej, a stosowane także w psychologii społecznej, okazują się pomocne $\mathrm{w}$ interpretacji przytoczonego fragmentu dzieła. W sytuacji pokusy zachodzi konflikt między standardem wartości a standardem korzyści. Rozwiązanie na korzyść standardu wartości zależy od poziomu uwewnętrznienia wartości. Im dana wartość należy do bardziej cenionych, pożądanych i realizowanych w życiu jednostki, tym większe prawdopodobieństwo, że w sytuacji pokusy człowiek wybierze kierunek działania zgodny z tą wartością (w tym przypadku z odwagą), a nie z korzyścią, np. zyskiem materialnym. Aby jednak wartość ta została uwewnętrzniona, proces socjalizacji musi przebiegać prawidłowo. W warunkach niezgodności norm: moralnych, prawnych, społecznych jest to zadanie niełatwe ${ }^{79}$. Wymowa zacytowanego fragmentu kroniki stanowi rów-

77 K. Olbrycht, Przygotowanie pedagogów do prowadzenia edukacji aksjologicznej. Wybrane aspekty, w: Edukacja aksjologiczna, t. 4, s. 11.

78 K. R. Prokop, Wincenty Kadłubek, s. 50.

79 K. Ostrowska, Wokót rozwoju osobowości i systemu wartości, Warszawa 1998, s. 7, 9. 
nież pochwałę konsekwencji w sprzeciwianiu się złu i związanego z nim upadku oraz pochwałę zarówno szlachetnych czynów wynikających z cnoty, jak i cnót prowadzących do szlachetności. Postawa szlachetności z pewnością nie ukształtuje się bez uprzedniego uosabiania dzielności etycznej. Nie bez powodu Stefan Wyszyński w homilii wygłoszonej w 1964 r. w Jędrzejowie przekonywał rodaków: „Bł. Wincenty żyje w nas [...] swoją duchowością. Obecny jest w naszym pokoleniu. My dzisiaj nie tylko go podziwiamy, ale żyjemy tymi wartościami moralnymi, które on nam przekazał"80.

Reasumując, niepoddawanie się strachowi, lękowi, niepokojowi, obawom, wątpliwościom, a przede wszystkim nihilizmowi, prowadzi do aktów odwagi i w rezultacie - do bycia dzielnym i mężnym. Przezwyciężanie wyliczonych stanów emocjonalnych oraz deficytów moralnych zachodzi za pośrednictwem wychowawczego kształtowania człowieka: wzorowania się na dzielnych przodkach, ćwiczenia się w cnocie dzielności, pokonując godnie trudne wydarzenia życiowe. Staje się możliwe także dzięki samodzielnemu zdobywaniu się na odwagę, i w ten sposób sukcesywnemu urzeczywistnianiu w sobie dzielności. Ludzie dzielni są zazwyczaj postrzegani pozytywnie, gdyż w ich wizerunek wpisana zostaje samodzielność, zaradność i niezależność, a nawet umiejętność chronienia innych.

\section{Podsumowanie}

Do ważnego dorobku historiografii średniowiecznej XII i początków XIII w. należy napisane po łacinie dzieło literatury polskiej Chronicon Polonorum (Kronika polska) autorstwa biskupa krakowskiego i jednego z reformatorów Kościoła kapelana nadwornego Kazimierza II Sprawiedliwego, pierwszego polskiego kronikarza - Wincentego Kadłubka. Ze względu na rzadką recepcję myśli pedagogicznej tego średniowiecznego myśliciela badaniu poddano część osiągnięć dziejopisarskich kronikarza należących do dorobku aksjologii i aretologii. Kategoria aksjologiczna - „odwaga” i kategorie aretologiczne - „dzielność" i męstwo mają bowiem, oprócz niewątpliwych związków z etyką, psychologią, socjologią, teologią, wyraźne usytuowanie naukowe w pedagogice jako dyscyplinie.

8o K. Świżek ocist., Błogosławiony Wincenty Kadłubek, s. 96. 
Dzięki hermeneutycznej wnikliwości udzielono odpowiedzi na kilka pytań związanych z badanymi kategoriami, w wyniku czego można sformułować poniższe twierdzenia.

- Odwaga, tzw. dojrzała, w przekonaniu Kadłubka, przejawia się w optymalnej mierze cechy: dzielności, i tylko tę przedkłada kronikarz uwadze czytelników swego dzieła. Odwaga, dzielność i męstwo są natomiast, w jego przekonaniu, nietożsame z zaciekłością i zawziętością wynikającymi z nienawiści i pychy, a także z zuchwałością, dziarskością oraz brawurą.

- „Genezę" odwagi odnajdował dziejopisarz w uduchowieniu człowieka oraz w miłości ojczyzny, która w obywatelach wyzwala siły do jej obrony. Wysunął stosowne argumenty na potwierdzenie związku odwagi jako wartości i męstwa oraz dzielności jako cnót z innymi wartościami i cnotami, na przykład z uczciwością, roztropnością, cierpliwością, wielkodusznością oraz pobożnością.

- Zasadnicze znaczenie uosabiania dzielności i męstwa dostrzega Kadłubek w usuwaniu jej przeciwieństw na drodze osiągania dobrego życia, to znaczy prowadzącego do zbawienia. Nie pomija również udziału dzielności i męstwa w skutecznej walce ze złem, w przywracaniu pokoju, porządku publicznego wynikającego z respektowania m.in. zasad sprawiedliwości i miłości społecznej.

- Przeciwieństwem odwagi jest przede wszystkim bojaźliwość (inaczej tchórzostwo), utrudnieniami zaś w realizowaniu dzielności są także strach, lęk, obawa, niepokój, wątpliwość, rozterka, a przede wszystkim brak okazji do doskonalenia się w cnocie dzielności, czyli do jej systematycznego trenowania.

- Przezwyciężanie wyliczonych stanów emocjonalnych oraz deficytów moralnych zachodzi za pośrednictwem wychowawczego kształtowania człowieka: wzorowania się na dzielnych przodkach, ćwiczenia w cnocie dzielności, pokonując godnie przeciwności życiowe. Zachodzi także dzięki samodzielnemu zdobywaniu się na odwagę i w ten sposób sukcesywnemu urzeczywistnianiu w sobie dzielności.

Streszczenie: Ze względu na rzadką recepcję myśli pedagogicznej średniowiecznego myśliciela Wincentego Kadłubka autorka artykułu zdecydowała się poddać badaniu część osiągnięć dziejopisarskich kronikarza, którą daje się zakwalifikować do dorobku aksjologii (teorii wartości) i aretologii (teorii cnót). Kategorie „odwaga”, „dzielność” i "męstwo" mają bowiem, oprócz proweniencji etycznej, również wyraźne usytuowanie naukowe w dyscyplinie pedagogika i wielu jej subdyscyplinach. Istotne znaczenie tych kategorii ujawnia się zarówno w obszarze pedagogiki teoretycznej, jak i praktycznej. 
Oprócz przypomnienia specyficznych cech epoki, w jakiej żył oraz tworzył ten wyjątkowy w dziejach narodu polskiego intelektualista, a także zaprezentowania zwięźle kroniki i faktów biograficznych, niniejszy artykuł stanowi propozycję rozwiązania kilku problemów badawczych, jak np. Wincenty Kadłubek postrzega odwagę, dzielność i męstwo? Jak ujmuje „genezę" ludzkiej odwagi, dzielności i męstwa? Z jakimi innymi wartościami i cnotami są - w jego opinii - najsilniej związane? Jakie znaczenie przypisuje kronikarz uosabianiu dzielności i męstwa? Co stanowi, w jego przekonaniu, ich przeciwieństwa? Jakie przekazuje wskazówki odnośnie do przezwyciężania tych przeciwieństw, a także do wychowawczego kształtowania dzielności i męstwa? Autorka podjęła się hermeneutycznej interpretacji dorobku mistrza Wincentego w przekonaniu, że analizowane dziedzictwo stanowi kapitał kulturowy narodu, skarbnicę rodzimej tradycji, wciąż mającą wiele do zaoferowania nie tylko polskim naukowcom, lecz każdemu odbiorcy.

Słowa kluczowe: wartość, cnota, aksjologia, aretologia, odwaga, dzielność.

\section{Bibliografia}

\section{Źródła}

Magistri Vincentii dicti Kadłubek Chronicon Polonorum, wydał, wstęp i przypisy M. Plezia, seria: Monumenta Poloniae Historica. Nova series, t. 11, Kraków 1994.

Mistrz Wincenty Kadłubek, Kronika polska, przeł. B. Kürbis, Diepholz 2009.

Mistrz Wincenty Kadłubek, Kronika polska, przeł. B. Kürbis, Wrocław 1996.

Myśli i nauki Mistrza Wincentego zwanego Kadłubkiem, zebr. i przeł. B. Kürbis, Warszawa 1980.

\section{Opracowania}

Aretologia, w: Słownik przewodnik filozoficzny. Osoby - problemy - terminy, red. A. Maryniarczyk, P. Jaroszyński, H. Kiereś, Z. J. Zdybicka, Lublin 2012, s. 362.

Badanie biografii: źródła, metody, konteksty, red. R. Skrzyniarz, E. Krzewska, W. Zgłobicka-Gierut, Lublin 2014.

Bieniak J., Mistrz Wincenty w życiu politycznym Polski przełomu XII i XIII wieku, w: Mistrz Wincenty Kadłubek. Człowiek i dzieło, pośmiertny kult i legenda, red. K. R. Prokop, Kraków 2001, s. 21-48.

Bubczyk R., Kazimierz Sprawiedliwy - władca idealny mistrza Wincentego („Chronica Polonorum”), „Kwartalnik Historyczny”, 116 (2009) nr 1, s. 31-53.

Chmielewska K., Uczeni w średniowiecznych klasztorach. Wykształceni zakonnicy $w$ relacjach kronikarskich, w: Uczeni z odległej i nieodległej przeszłości. Rekonstrukcje, interpretacje, refleksje, red. A. Żywczok, M. Kitlińska-Król, Katowice 2019, s. 35-46. 
Cnoty i wady, w: Słownik przewodnik filozoficzny. Osoby - problemy - terminy, red. A. Maryniarczyk, P. Jaroszyński, H. Kiereś, Z. J. Zdybicka, Lublin 2012, s. 373.

Dawson Ch., Szkice o kulturze średniowiecznej, przeł. J. Sulowski, Warszawa 1966.

Grodecki R., Mistrz Wincenty, biskup krakowski (zarys biograficzny), „Rocznik Krakowski", 19 (1923) s. 30-61.

Grondin J., Wprowadzenie do hermeneutyki filozoficznej, przeł. L. Łysień, Kraków 2007.

Jan Paweł II, Cnota męstwa. Przemówienie na audiencji ogólnej 15. XI.1978, w: Jan Paweł II, Nauczanie społeczne 1978-1979, Warszawa 1982, s. 44-46.

Jan Paweł II, Wezwanie do męstwa. Przemówienie na konsystorzu publicznym 30 VI 1979, w: Jan Paweł II, Nauczanie społeczne 1978-1979, Warszawa 1982, s. 117-119.

Jan Paweł II, Zachowajcie odwagę i dumę z waszej wiary. Przemówienie w kaplicy ambasady włoskiej w Ankarze 29 XI 1979, w: Jan Paweł II, Nauczanie społeczne 1978-1979, Warszawa 1982, s. 377-380.

Jasienica P., Polska Piastów, Warszawa 1985.

Jasienica P., Trzej kronikarze, Warszawa 1992.

Jaśtal J., Etyka i czas. Wariacje aretologiczne, Kraków 2015.

Kadłubek Wincenty, w: Stownik przewodnik filozoficzny. Osoby - problemy - terminy, red. A. Maryniarczyk, P. Jaroszyński, H. Kiereś, Z. J. Zdybicka, Lublin 2012, s. 146-147.

Korolec J., Ideał władcy w Kronice mistrza Wincentego, w: Pogranicza i konteksty literatury polskiego średniowiecza, red. T. Michałowska, Wrocław 1989, s. 71-87.

Kuksewicz Z., Zarys filozofii średniowiecznej. Filozofia łacińskiego obszaru kulturowego, Warszawa 1973.

Kürbis B., Jak Mistrz Wincenty pisał historię Polski, w: Mistrz Wincenty Kadłubek. Człowiek i dzieło, pośmiertny kult i legenda, red. K. R. Prokop, Kraków 2001, s. 59-78.

Kürbis B., Przedmowa, w: Myśli i nauki Mistrza Wincentego zwanego Kadłubkiem, zebr. i przeł. B. Kürbis, Warszawa, Państwowy Instytut Wydawniczy, 1980, s. 6-17.

Lekka-Kowalik A., Cnota, w: Encyklopedia aksjologii pedagogicznej, red. K. Chałas, A. Maj, Radom 2016, s. 168-174.

MacIntyre A., Dziedzictwo cnoty. Studium z teorii moralności, przeł. A. Chmielewski, Warszawa 1996.

Mańkowski J., Krak, uczeń Sokratesa (glosa do Kadłubka Chronica Polonorum I 5,3), w: Inspiracje platońskie literatury staropolskiej. Materiały z konferencji zorganizowanej przez Zespół Badań Literackich nad Historiq Kultury Epok Dawnych Instytutu Literatury Polskiej Uniwersytetu Warszawskiego 14-15 października 1998 r., red. A. Nowicka-Jeżowa, P. Stępień, Warszawa 2000, s. 147-150.

Matla-Kozłowska M., Wstęp do Kroniki polskiej Mistrza Wincentego Kadłubka, w: Mistrz Wincenty Kadłubek, Kronika polska, przeł. B. Kürbis, Diepholz 2009.

Michałowska T., Literatura polskiego średniowiecza wobec poetyki europejskiej („Ornatus difficilis"), Warszawa 2008. 
Michałowska T., Szkice mediewistyczne, seria: Studia Staropolskie. Series Nova, t. 40 (96), Warszawa 2014.

Milerski B., Hermeneutyka pedagogiczna. Perspektywy pedagogiki religii, Warszawa 2011. Magistri Vincentii dicti Kadłubek Chronicon Polonorum, wydał, wstęp i przypisy M. Plezia, seria: Monumenta Poloniae Historica. Nova series, t. 11, Kraków 1994.

Olbrycht K., Przygotowanie pedagogów do prowadzenia edukacji aksjologicznej. Wybrane aspekty, w: Edukacja aksjologiczna, t. 4: Wybrane problemy przekazu wartości, red. K. Olbrycht, Katowice 1999, S. 11-20.

Ostrowska K., Wokół rozwoju osobowości i systemu wartości, Warszawa 1998.

Ostrowska K., Wychowywać do urzeczywistniania wartości, w: Edukacja aksjologiczna, t. 4: Wybrane problemy przekazu wartości, red. K. Olbrycht, Katowice 1999, s. 21-33.

Ostrowska U., Doświadczanie conditio humana przez człowieka współczesnego. W trosce o człowieczeństwo z perspektywy aksjologicznej, Gorzów Wielkopolski 2020.

Plezia M., Mistrz Wincenty zwany Kadłubkiem, w: Pisarze staropolscy, sylwetki, t. 1, red. S. Grzeszczuk, Warszawa 1991, s. 93-131.

Plezia M., Retoryka Mistrza Wincentego, „Studia Źródłoznawcze”, 20 (1976) s. 88-94.

Prokop K. R., Wincenty Kadłubek, Kraków 2005.

Przedmiot, źródła i metody badań w biografii, red. R. Skrzyniarz, L. Dziaczkowska, D. Opozda, Lublin 2016.

Przyłębski A., Hermeneutyka. Od sztuki interpretacji do teorii i filozofii rozumienia, Poznań 2019.

Samek J., Błogosławiony Wincenty Kadłubek w sztuce (rozeznanie problemu), w: Mistrz Wincenty Kadłubek. Człowiek i dzieło, pośmiertny kult i legenda, red. K. R. Prokop, Kraków 2001, s. 93-101.

Samsonowicz H., Sytuacja polityczna Polski w czasach Wincentego, w: Onus Athlanteum. Studia nad Kronika biskupa Wincentego, red. A. Dąbrówka, W. Wojtowicz, Warszawa 2009, s. 29-38.

Słownik pojęć filozoficznych, red. W. Krajewski, Warszawa 1994.

Stępień A. B., Wstęp do filozofii, Lublin 2001.

Stróżewski W., Istnienie i wartość, Kraków 1981.

Sulowski J., Elementy filozofii XII wieku w Kronice mistrza Wincentego, „Studia Źródłoznawcze", 20 (1976) s. 19-21.

Świżek K. ocist., Błogosławiony Wincenty Kadłubek. Życie - kult - modlitwy, Jędrzejów 1999.

Tomasz z Akwinu, Suma teologiczna, t. 21: Męstwo, przeł. S. Bełch, P. Bełch, Londyn 1962.

Wartość, w: Słownik przewodnik filozoficzny. Osoby - problemy - terminy, red. A. Maryniarczyk, P. Jaroszyński, H. Kiereś, Z. J. Zdybicka, Lublin 2012, s. 502.

Wartość i sens. Aksjologiczne aspekty teorii interpretacji, red. A. Tyszczyk, E. Fiały, R. Zajączkowski, Lublin 2003. 
Wenc A., Odwaga, w: Encyklopedia aksjologii pedagogicznej, red. K. Chałas, A. Maj, Radom 2016, s. 678-680.

Wiszewski P., Polska w kronice Mistrza Wincentego. Ze studiów nad terminologią dzieła i hierarchiami wartości w Polsce petnego średniowiecza, w: Onus Athlanteum. Studia nad Kronika biskupa Wincentego, red. A. Dąbrówka, W. Wojtowicz, Warszawa 2009, s. 75-90.

Witkowska A., Górski K., Wzorce ideowe zachowań ludzkich w XII i XIII wieku, w: Polska dzielnicowa i zjednoczona. Państwo, społeczeństwo, kultura, red. A. Gieysztor, Warszawa, 1972, s. 119-158.

Wyrozumski J., Kraków i Małopolska w czasach Mistrza Wincentego Kadłubka, w: Mistrz Wincenty Kadłubek. Człowiek i dzieło, pośmiertny kult i legenda, red. K. R. Prokop, Kraków 2001, s. 13-19.

Zabielski J., Roztropność, męstwo, umiarkowanie i sprawiedliwość jako wyznaczniki chrześcijańskiej moralności. Studium tomistyczno-aksjologiczne, Warszawa 2015, s. 49-65.

Zdrenka M. T., O gnuśności: studium lenistwa i jego kontekstów, Toruń 2012.

Żywczok A., Formy odwagi ludzkiej i sposoby jej identyfikacji w procesie wychowania, „Kwartalnik Pedagogiczny”, 1 (2008) s. 55-68.

Żywczok A., Reaktywowanie idei odwagi i etycznej dzielności w wychowaniu dzieci i młodzieży, „Chowanna”, 1 (2008) s. 37-55. 